\title{
PENGARUH CORPORATE SOCIAL RESPONSIBILITY, KUALITAS AUDIT DAN UKURAN PERUSAHAAN TERHADAP CORPORATE SUSTAINABILITY REPORTING
}

\author{
Nutriastuti ${ }^{1)}$, Dea Annisa ${ }^{2)}$ \\ Universitas Pamulang, Tangerang Selatan, Indonesia \\ Email:dosen00883@unpam.ac.id
}

\begin{abstract}
This study aimed to get empirical evidence about the influence of Corporate Social Responsibility Disclosure and Quality Audit to Corporate Sustainability Reporting. Corporate Social Responsibility Disclosure was proxied by CSRDI (Corporate social responsibility disclosure index) based on indicators GRI 2016. Audit quality was proxied by big-four accounting firm or non big-four and measured by a dummy variable. The level of Corporate Sustainability Reporting disclosure measured through Sustainability Report Disclosure Index (SRDI) is expressed by comparing the number of disclosures by the company with a number of standar disclosure of the Global Reporting Initiative (GRI) 2016 index. The type of research is an associative quantitative research with the determination of samples testing purposive sampling method, of obtaining samples based on certain criteria. The data used is secondary data collected through companies listed on The Indonesia Stock Exchange. Hypothesis testing is done by technique, classic assumption test analysis and multiple linear regression test analysis used in this study to answer the main problem of research. The data collecied, then processed and analyzed using the program SPSS 25.0 for windows. The result of this study indicate that Corporate Social Responsibility has a significant positive effect on Corporate Sustainability Reporting. Audit Quality has no significant positive effect on Corporate Sustainability Reporting. SIZE has no significant positive effect on Corporate Sustainability Reporting. Simultaneous hypothesis testing shows that Corporate Social Responsibility, Audit Quality and SIZE together have a significant positive effect on Corporate Sustainability Reporting.
\end{abstract}

Keywords: Corporate Social Responsibility; Kualitas Audit; SIZE; Corporate Sustainability Reporting

\begin{abstract}
Abstrak
Penelitian ini bertujuan untuk memperoleh bukti empiris mengenai pengaruh pengungkapan Corporate Social Responsibility dan Kualitas Audit terhadap Corporate Sustainability Reporting. Pengungkapan Corporate Social Responsibility diukur dengan proksi CSRDI (Corporate social responsibility disclosure index) berdasarkan indikator GRI 2016. Kualitas Audit diproksikan dengan KAP big four atau non-big four dan diukur dengan variabel dummy.
\end{abstract}


Jurnal Akuntansi Berkelanjutan Indonesia - Vol. 3, No. 2, Mei 2020 - Nutriastuti \& Annisa

Tingkat pengungkapan informasi Corporate Sustainability Reporting diukur melalui Sustainability Report Disclosure Index (SRDI) dinyatakan dengan membandingkan jumlah pengungkapan yang dilakukan perusahaan dengan jumlah standar pengungkapan Global Reporting Initiative (GRI) 2016 Indeks. Jenis penelitian ini merupakan penelitian kuantitatif asosiatif dengan penentuan sampel menggunakan metode purposive sampling, yaitu memperoleh sampel berdasarkan kriteria tertentu. Data yang digunakan adalah data sekunder yang dikumpulan melalui perusahaan yang terdaftar di Bursa Efek Indonesia. Pengujian hipotesis dilakukan dengan teknik analisis uji asumsi klasik dan uji regresi linear berganda digunakan dalam penelitian ini untuk menjawab permasalahan pokok penelitian. Data yang dikumpulkan, kemudian diolah dan dianalisis dengan menggunakan aplikasi SPSS 25.0 for Windows. Hasil penelitian ini menunjukkan bahwa pengungkapan Corporate Social Responsibility berpengaruh signifikan positif terhadap Corporate Sustainability Reporting. Kualitas Audit tidak berpengaruh signifikan positif terhadap Corporate Sustainability Reporting. Ukuran Perusahaan tidak berpengaruh signifikan positif terhadap Corporate Sustainability Reporting. Pengujian hipotesis simultan menunjukkan bahwa pengungkapan Corporate Social Responsibility, Kualitas Audit dan Ukuran Perusahaan secara bersama-sama berpengaruh signifikan positif terhadap Corporate Sustainability Reporting.

Kata kunci: Corporate Social Responsibility; Kualitas Audit; Ukuran Perusahaan; Corporate Sustainability Reporting

\section{PENDAHULUAN}

Seiring banyaknya terjadi bencana lingkungan hidup, perusahaan industri minuman diduga membuang limbah berbahaya yang akan menyebabkan polusi parah. Ada indikasi bahwa limbah yang dikeluarkan oleh perusahaan yang berlokasi di perbatasan Kota Bekasi dan Kabupaten Bogor membuang limbah yang tak sesuai dengan baku mutu yang ada. Sebelumnya diketahui bahwa air Sungai Bekasi tercemar berat (20/01/14). Dampak PDAM Tirta Patriot adalah berhenti memproduksi air bersih karena air baku mengandung limbah berbahaya lebih dari 2 buku berkualitas. Sekitar 26.300 pelanggan tidak memiliki air bersih. (Dilansir dari merdeka.com, 2017)

Dari kasus di atas, kini pemerintah mengambil tindakan agar tidak berlangsungnya penyimpangan perusahaan terhadap lingkungan sekitarnya. Seperti halnya, Kementerian Lingkungan Hidup dan Kehutanan (KLHK) mengeluarkan program penilaian peringkat kinerja perusahaan (Proper), Kamis (27/12/18). Terdapat 1.906 perusahaan yang berpartisipasi dalam penilaian, sebanyak 20 telah mendapatkan predikat emas, 155 predikat hijau, 1.454 biru, 241 merah dan dua perusahaan predikat hitam. Perusahaan yang predikatnya tidak diumumkan ada sebanyak 32, serta ada 16 perusahaan kena hukum dan 18 tak

* Corresponding author's e-mail: : dosen00883@unpam.ac.id

http://openjournal.unpam.ac.id/index.php/JABI 
Jurnal Akuntansi Berkelanjutan Indonesia - Vol. 3, No. 2, Mei 2020 - Nutriastuti \& Annisa

beroperasi. Sementara penghematan biaya oleh perusahaan-perusahaan ikut Proper total Rp 925,241 triliun, naik 16 kali lipat dibanding tahun sebelumnya, Rp 53,076 triliun. Proper, sudah bertransformasi dari kriteria penilaian pengendalian paling sederhana yaitu pencemaran air berkembang jadi kriteria multi dimensi aspek lingkungan meliputi pengendalian pencemaran air, pengendalian pencemaran udara, serta pengelolaan limbah berbahaya. Penilaian Proper sudah mewajibkan perhitungan jumlah penghematan biaya dari inovasi-inovasi itu. Bukti efisiensi dan penghematan biaya ini dianggap mampu mengubah presepsi para pemimpin perusahaan yang dahulu mengganggap mengelola lingkungan merupakan beban biaya bagi perusahaan, ternyata dapat memberikan keuntungan bagi perusahaan. (Dalam situs berita lingkungan mongabay.ac.id, 31/12/2018).

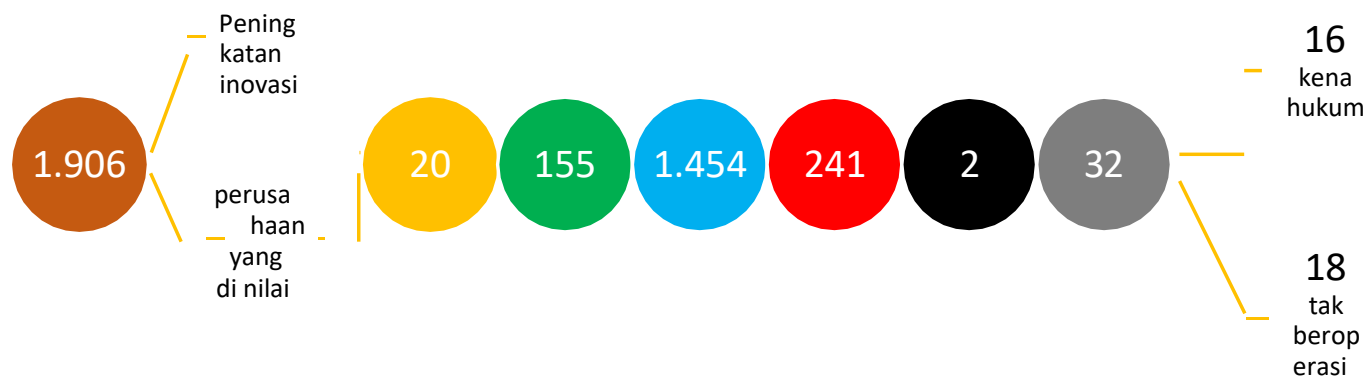

\section{Gambar 1 \\ Peningkatan Inovasi dan Perusahaan yang dinilai \\ Sumber: Data yang diolah (2019)}

Pemerintah Indonesia juga memberikan dukungan terhadap sustainability reporting dengan mengeluarkan peraturan pemerintah, di antaranya UU No. 32 Tahun 2009 tentang Perlindungan dan Pengelolaan Lingkungan Hidup dalam Pasal 1 ayat (3) mengenai pembangunan berkelanjutan, UU No. 25 Tahun 2007 tentang Penanaman Modal, UU No. 40 Pasal 66 ayat (2) dan Pasal 74 tahun 2007. Pasal 66 ayat (2) bagian c berisi bahwa selain menyampaikan laporan keuangan. Perusahaan juga dituntut untuk membuat laporan Tanggung Jawab Sosial Perusahaan dan Lingkungan.

Perusahaan- perusahaan di Indonesia dalam melaksanakan tanggung jawab sosial dan lingkungan terdorong oleh undang-undang, kemudian dibuat laporan keberlanjutan (sustainability report) terintegrasi dalam laporan tahunan perusahaan. Konsep pembangunan berkelanjutan membuat cara pandang para manajemen perusahaan tentunya lebih ke prospek ke depan yang lebih baik. Sebelumnya perusahaan hanya memperhatikan tingkat laba, sekarang mulai memperhatikan aspek lingkungan, yang lebih dikenal dengan konsep triple bottom line. Dalam pencapaian pembangunan berkelanjutan, perusahaan membutuhkan kerangka kerja global yang menggunakan bahasa yang konsisten dan mudah dipahami. Konsep tersebut dikenal sebagai laporan berkelanjutan. Konsep triple bottom line yang dikembangkan oleh Elklington pada tahun 1988 bertujuan untuk

* Corresponding author's e-mail: : dosen00883@unpam.ac.id

http://openjournal.unpam.ac.id/index.php/JABI 
Jurnal Akuntansi Berkelanjutan Indonesia - Vol. 3, No. 2, Mei 2020 - Nutriastuti \& Annisa

mendukung proses pembangunan yang berkelanjutan yang mencakup tiga aspek yaitu aspek ekonomi, sosial dan lingkungan.

Tidak adanya aturan di Indonesia yang mewajibkan seperti halnya penerbitan financial reporting. Hal ini disebabkan meningkatnya peraturan lingkungan di banyak negara yang diharapkan lebih ketat.

Penelitian tentang pelaporan sosial dan lingkungan atau sustainability reporting terus berkembang dan sudah memiliki alur penelitian, khususnya mengenai Corporate Social Responsibility terhadap Sustainability Reporting (Ibrahim, 2016). Di beberapa penelitian, salah satu komponen yang diikusertakan sebagai bagian dari setiap dimensi Corporate Social Responsibility yang terdiri dari Ekonomi, Lingkungan, Tenaga Kerja, Hak Asasi Manusia, Masyarakat dan Tanggung Jawab Produk memiliki pengaruh positif dan signifikan terhadap Sustainability Reporting. Penelitian William (2012), menyatakan bahwa pengungkapan Corporate Social Responsibility secara keseluruhan dan setiap dimensi CSR memiliki pengaruh positif dan signifikan terhadap nilai perusahaan.

Penelitian lain yang dilakukan oleh M. Yusuf (2016) yang menyebutkan bahwa pengaruh kualitas audit terhadap Sustainability Reporting menunjukan bahwa kualitias audit tidak berpengaruh secara signifikan terhadap Sustainability Reporting. Hasil ini berbanding terbalik dengan penelitian Ryandi Iswandika (2014) dalam jurnal M. Yusuf Ibrahim (2016). Pada penelitian lain yang dilakukan oleh beberapa penelitian membuktikan bahwa ukuran perusahaan terhadap Corporate Sustainability Reporting, di antaranya: Widianto (2011), Ratnasari (2011), Suryono dan Prastiwi (2011), Ibrahim (2016), Raharjo (2016), Adawiyah (2016), Rohmah (2015), Nasir., dkk (2014), Luthfia (2012), Ahmad (2014), Putri (2013) berpengaruh.

Penelitian ini berfokus pada semua perusahaan yang menerbitkan laporan keberlanjutan atau pelaporan keberlanjutan atas dasar sukarela dan terdaftar di Bursa Efek Indonesia karena perusahaan ini memiliki dampak atau pengaruh langsung terhadap lingkungan, seperti proses atau kursus kegiatan bisnis, polusi dan efek sosial pada komunitas.

Penelitian ini menggunakan Global Reporting Intitative (GRI) sebagai indeks pengungkapan sustainability reporting dengan pertimbangan. Penelitian ini menggabungkan variabel Coporate Social Responsibility dan Kualitas Audit sebagai variabel independen. Corporate Sustainability Reporting sebagai variabel dependen dan ukuran perusahaan sebagai variabel kontrol. Dalam penelitian ini yang dijadikan sampel ialah perusahaan yang terdaftar di Bursa Efek Indonesia (BEI) yang menerbitkan laporan keberlanjutan atau Corporate Sustainability Reporting pada periode tahun 2017-2018.

Peneliti bermaksud melakukan penelitian tentang Pelaporan Keberlanjutan Perusahaan, yang selalu mengalami perkembangan sebagai referensi standar ketika menggambarkan keadaan perusahaan. Hingga banyak dari perusahaan tersebut atau perusahaan baru mengalami peningkatan dari tahun ketahun untuk menerbitkan laporan keberlanjutan karena termotivasi akan kondisi yang terjadi Berdasarkan uraian diatas, maka penulis merumuskan masalah sebagai berikut: "Pengaruh Pengungkapan Corporate Social Responsibility dan Kualitas Audit terhadap Sustainability Reporting Pada Perusahaan yang Terdaftar di Bursa Efek 
Jurnal Akuntansi Berkelanjutan Indonesia - Vol. 3, No. 2, Mei 2020 - Nutriastuti \& Annisa

Indonesia Tahun 2017-2018”.

\section{KERANGKA TEORITIS DAN PENGEMBANGAN HIPOTESIS}

Teori sinyal merupakan teori yang menjelaskan tentang bagaimana perusahaan memberikan sinyal-sinyal kepada pengguna laporan keuangan. Teori ini dikaitkan pada variabel Sustainability Reporting dan Kualitas Audit yang sesuai dengan harapan stakeholder digunakan sebagai sinyal goodnews yang diberikan kepada pihak manajemen dan publik bahwa perusahaan memiliki prospek yang baik di masa depan dan memastikan terciptanya sustainability development.

Teori Legitimasi didasarkan atas gagasan bahwa bisnis perusahaan yang beroperasi di masyarakat memiliki kontrak sosial dimana melakukan tindakan yang diinginkan oleh masyarakat sebagai balasan atas diterimanya tujuan perusahaan. Teori ini dikaitkan pada variabel Corporate Social Responsibility, yaitu sebagai Pengurangan dari gap legitimasi menurut O'Donovan (2002) dalam dapat dilakukan dengan memperluas wilayah kesesuaian antara operasi perusahaan dengan pengharapan masyarakat dengan cara melakukan strategi legitimasi dan melakukan pendekatan social disclosure.

\section{Corporate Social Responsibility}

Pengungkapan tanggung jawab sosial diukur dengan proksi CSRDI (Corporate social responsibility disclosure index) berdasarkan indikator GRI (Global reporting initiatives) Penelitian ini menggunakan standar yang sesuai dengan pedoman Global Reporting Initiatives (GRI) 2016 yang di peroleh dari website www.globalreporting.org, yang terdiri dari kategori ekonomi (13 indikator), lingkungan (32 indikator), dan sosial (40 indikator).

$$
\mathrm{CSRD}=\frac{\mathrm{N}}{\mathrm{R}}
$$

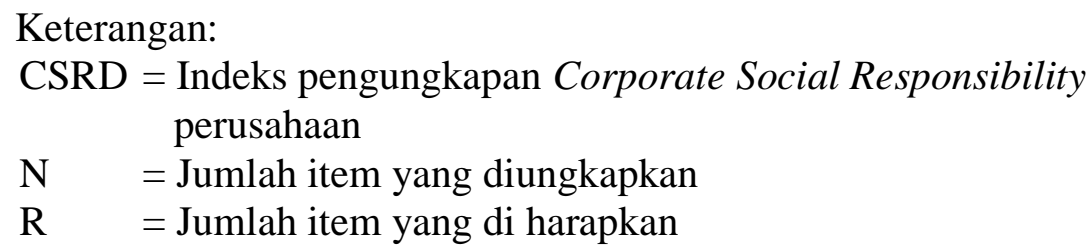

\section{Kualitas Audit}

Kualitas audit sebagai probabilitas dimana seorang auditor menemukan dan melaporkan tentang adanya suatu pelanggaran dalam sistem akuntansi kliennya.

Kualitas Audit (KUAD) yang ditentukan oleh laporan keuangan yang diaudit oleh kantor akuntan big four dan kantor akuntan non-big four (Andriyanto, Effriyanti \& Hidayat, 2018). Variabel ini diukur dengan menggunakan variabel dummy, yaitu 0 apabila auditor berasal dari kantor akuntan non-big four dan 1 apabila auditor berasal dari kantor akuntan big four.

* Corresponding author's e-mail: : dosen00883@unpam.ac.id

http://openjournal.unpam.ac.id/index.php/JABI 
Jurnal Akuntansi Berkelanjutan Indonesia - Vol. 3, No. 2, Mei 2020 - Nutriastuti \& Annisa

$$
\begin{gathered}
1=\text { KAP big } 4 \\
0=\text { KAP non big } 4
\end{gathered}
$$

\section{Ukuran Perusahaan}

Ukuran perusahaan dapat diukur dengan menggunakan total aset, penjualan, atau ekuitas (Almilia, 2007). Dalam penelitian ini variabel ukuran perusahaan diukur dengan menggunakan nilai log of total asset yang dimiliki oleh masingmasing perusahaan, tujuannya agar mengurangi perbedaan yang signifikan antara ukuran perusahaan besar dan ukuran perusahaan kecil sehingga data total asset dapat terdistribusi normal. Rumus yang digunakan adalah:

$$
\text { Size }=\text { Log natural }(\text { Total aset })
$$

\section{Sustainability Reporting}

Variabel ini diukur melalui Sustainability Report Disclosure Index (SRDI). SRDI menilai tanggung jawab sosial yang sesuai dengan kriteria menurut GRI, yaitu: Umum, Ekonomi, Lingkungan dan Sosial. Dari 4 aspek pengungkapan sustainability reporting hanya 1 aspek yang sesuai untuk penelitian Sustainability Reporting terdapat 30 item yang kemudian disesuaikan kembali dengan masingmasing perusahaan. Rumus perhitungan SRDI adalah:

$$
\mathrm{SRDI}=\frac{V}{M}
$$

Keterangan:

SRDI = Sustainability Report Disclosure Index perusahaan

$\mathrm{V} \quad=$ Jumlah item yang diungkapkan perusahaan

$\mathrm{M} \quad=$ Jumlah item yang diharapkan

\section{Pengembangan Hipotesis}

\section{Corporate Social Responsibility berpengaruh terhadap Corporate Sustainability Reporting}

Di dalam beberapa penelitian sebelumnya terbukti bahwa masing-masing dimensi di dalam pengungkapan Corporate Social Responsibility juga memiliki dampak tersendiri terhadap Corporate Sustainability Reporting. Dimulai dari dimensi pertama yaitu dimensi ekonomi, Gao (2009) dan Lindgreen et al. (2009a dan 2009b) Dimensi kedua adalah dimensi lingkungan yang juga memiliki pengaruh tersendiri terhadap nilai perusahaan yang tertuang dalam Sustainability Reporting. Perusahaan yang bertanggung jawab atas produknya akan berdampak pada peningkatan penjualan dan nilai perusahaan. Hipotesis yang diajukan sebagai berikut:

H1: Diduga Corporate Social Responsibility berpengaruh positif terhadap Sustainability Reporting

* Corresponding author's e-mail: : dosen00883@unpam.ac.id

http://openjournal.unpam.ac.id/index.php/JABI 
Jurnal Akuntansi Berkelanjutan Indonesia - Vol. 3, No. 2, Mei 2020 - Nutriastuti \& Annisa

\section{Kualitas Audit berpengaruh terhadap Corporate Sustainability Reporting}

Kualitas audit adalah analisis terhadap kualitas yang ditinjau dari aturan yang dibuat oleh aparatur pemerintah. Kemudian dari tiga pendekatran tersebut, mengidentifikasi adanya hubungan antara atribut kualitas audit dan kualitas audit yang dirasakan (dalam Lowensohn, 2007).

Perusahaan yang diaudit oleh KAP yang berukuran besar diasumsikan dapat mengerluarkan laporan keuangan yang lebih berkualitas berdasarkan regulasi yang telah ditentukan, karena memiliki kualitas, reputasi, dan kredibilitas dibanding KAP ukuran kecil. Berdasarkan uraian tersebut, maka hipotesis yang diajukan sebagai berikut:

H2: Diduga Kualitas Audit berpengaruh positif terhadap Sustainability Reporting

\section{Ukuran Perusahaan terhadap Corporate Sustainability Reporting.}

Perusahaan yang besar akan semakin terlihat oleh para stakeholder. Perusahaan membutuhkan usaha yang lebih besar untuk memperoleh legitimasi stakeholder. Oleh karena itu perusahaan yang digolongkan memiliki aset yang lebih besar akan semakin berkepentingan untuk mengungkap informasi yang lebih luas (Suryono dan Prastiwi, 2011). Hal ini karena semakin besar ukuran perusahaan maka semakin besar pula informasi yang terkandung di dalamnya, sehingga perusahaan terdorong untuk melakukan praktik pengungkapan sustainability report. Hipotesis yang diajukan sebagai berikut:

H3: Diduga Ukuran Perusahaan berpengaruh positif terhadap Sustainability Reporting.

Corporate Social Responsibility dan Kualitas Audit berpengaruh terhadap Corporate Sustainability Reporting.

Menurut penelitian Mulkhan dan Pratama (2011) tentang Kebijakan Pelaksanaan Corporate Social Responsibility sangat diperlukan untuk memberikan dorongan dan perhatian serius pada dunia usaha agar lebih termotivasi dalam pelaksanaan program Corporate Social Responsibility. Dan didalam penelitian Iswandika (2014) bahwa adanya hubungan antara Kualitas Audit terhadap Corporate Social Responsibility yang dinilai terhadap KAP yang mengaudit perusahaan tersebut. Berdasarkan uraian tersebut, maka hipotesis yang diajukan sebagai berikut:

H4: Diduga Corporate Social Responsibility dan Kualitas Audit berpengaruh positif terhadap Sustainability Reporting.

* Corresponding author's e-mail: : dosen00883@unpam.ac.id

http://openjournal.unpam.ac.id/index.php/JABI 
Jurnal Akuntansi Berkelanjutan Indonesia - Vol. 3, No. 2, Mei 2020 - Nutriastuti \& Annisa

\section{METODE RISET}

Penelitian ini termasuk penelitian deskriptif kuantitatif dengan menggunakan data sekunder yang diambil dari perusahaan yang terdaftar dalam Bursa Efek Indonesia (BEI) yang mempublikasikan Sustainability Reporting. Dimana tujuan penelitian ini untuk mengetahui pengaruh Corporate Social Responsibility dan Kualitas Audit terhadap Pengungkapan Sustainability Reporting. Penelitian ini dilakukan di Bursa Efek Indonesia (BEI) selama periode 2 tahun yaitu tahun 2017-2018. Pemilihan lokasi penelitian di Bursa Efek Indonesia (BEI) melalui situs resminya $w w w . i d x . c o . i d$ dan mengunjungi situs website resmi dari semua perusahaan yang tercatat di Bursa Efek Indonesia (BEI).

Terdapat 207 Perusahaan dari sektor manufaktur pertambangan dan perdagangan besar yang dijadikan populasi dalam penelitian ini. Pemilihan sampel menggunakan purposive sampling dengan kriteria sebagai berikut:

\section{Tabel 1}

Krieria Perusahaan

\begin{tabular}{|l|l|l|}
\hline No. & Kriteria Sampel & Jumlah \\
\hline 1 & $\begin{array}{l}\text { Sampel dari perusahaan non keuangan yang terdaftar dalam Bursa } \\
\text { Efek Indonesia (BEI) pada tahun 2013-2016 }\end{array}$ & 207 \\
\hline 2 & $\begin{array}{l}\text { Sampel dari perusahaan non keuangan yang tidak menerbitkan } \\
\text { laporan keuangan selama periode 2013-2016 }\end{array}$ & $(26)$ \\
\hline 3 & Sampel dari perusahaan yang menggunakan mata uang asing & $(53)$ \\
\hline 4 & $\begin{array}{l}\text { Sampel dari perusahaan non keuangan yang tidak menerbitkan } \\
\text { sustainability report berturut-turut selama periode 2013-2016. }\end{array}$ & $(120)$ \\
\hline Jumlah sampel selama periode penelitian selama 4 tahun & $\mathbf{3 2}$ \\
\hline
\end{tabular}

Sumber: Data yang diolah (2019)

\section{ANALISIS DATA DAN PEMBAHASAN}

Dalam melakukan analisis statistik terhadap data dari variabel yang akan diteliti, peneliti akan menggunakan metode analisis statistik deskriptif, analisa regresi linear berganda, uji koefisien determinasi, korelasi serta uji hipotesis secara parsial dan simultan. Sebelum melakukan analisa tersebut, maka diperlukan pengujian terhadap data yang akan digunakan dalam analisa tersebut, yaitu dengan melakukan uji pra analisa menggunakan uji asumsi klasik.

\section{Analisis Statistik Deskriptif}

Statistik Deskriptif digunakan untuk menggambarkan karakteristik data responden dan mengetahui nilai minimum, maksimal, rata-rata dan standar devisiasi pada suatu variabel. Responden dalam penelitian ini adalah Laporan Tahunan pada perusahaan yang tercatat di Bursa Efek Indonesia (BEI) yang menggunakan indeks GRI 2016 selama periode 2017-2018. 
Jurnal Akuntansi Berkelanjutan Indonesia - Vol. 3, No. 2, Mei 2020 - Nutriastuti \& Annisa

Tabel 2

Hasil Statistik Deskriptif

Descriptive Statistics

\begin{tabular}{l|r|r|r|r|r} 
& N & Minimum & Maximum & Mean & Std. Deviation \\
\hline CSR & 30 &, 04 &, 41 &, 1980 &, 10131 \\
\hline KA & 30 &, 00 & 1,00 &, 9000 &, 30513 \\
\hline SIZE & 30 & 29,21 & 34,72 & 31,7784 & 1,56056 \\
\hline SR & 30 &, 57 &, 65 &, 6139 &, 01809 \\
\hline Valid N (listwise) & 30 & & & & \\
\hline \multicolumn{2}{r|}{ Sumber: Data yang diolah SPSS 25.0 (2019) }
\end{tabular}

Dilihat dari tabel 2 menunjukkan bahwa Ukuran Perusahaan memiliki nilai minimum, rata-rata dan standar deviasi di atas 0. Pada variabel Corporate Social responsibility (CSR) dan Sustainability Reporting (SR) memiliki nilai maximum yaitu 0,41 dan 0,65 sedangkan Kualitas Audit (KA) dan Ukuran Perusahaan (SIZE) memiliki nilai yaitu 1,00 dan 34,72.

\section{Analisis Uji Asumsi Klasik}

Uji Normalitas

a. Uji Kolmogorov-Smirnov

Tabel 3

Hasil Uji Kolmogorov-Smirnov Test

One-Sample Kolmogorov-Smirnov Test

\begin{tabular}{llr} 
& & $\begin{array}{c}\text { Unstandardiz } \\
\text { ed Residual }\end{array}$ \\
\hline N & Mean & 30 \\
\hline Normal Parameters & a,b &, 0000000 \\
\cline { 2 - 3 } & Std. Deviation &, 01544420 \\
\hline Most Extreme Differences & Absolute &, 142 \\
\cline { 2 - 3 } & Positive &, 105 \\
\cline { 2 - 3 } & Negative &,- 142 \\
\hline Test Statistic & &, 142 \\
\hline Asymp. Sig. (2-tailed) & &, $127^{\mathrm{c}}$ \\
\hline
\end{tabular}
a. Test distribution is Normal.
b. Calculated from data.
c. Lilliefors Significance Correction.

Sumber: Data yang diolah SPSS 25.0 (2019)

* Corresponding author's e-mail: : dosen00883@unpam.ac.id

http://openjournal.unpam.ac.id/index.php/JABI 
Jurnal Akuntansi Berkelanjutan Indonesia - Vol. 3, No. 2, Mei 2020 - Nutriastuti \& Annisa

Pada tabel 3 kita dapat melihat nilai Asymp.Sig. (2-tailed) sebesar ,127 atau 0,127 . sehingga lulus uji normalitas.

\section{b. Uji P-Plot}

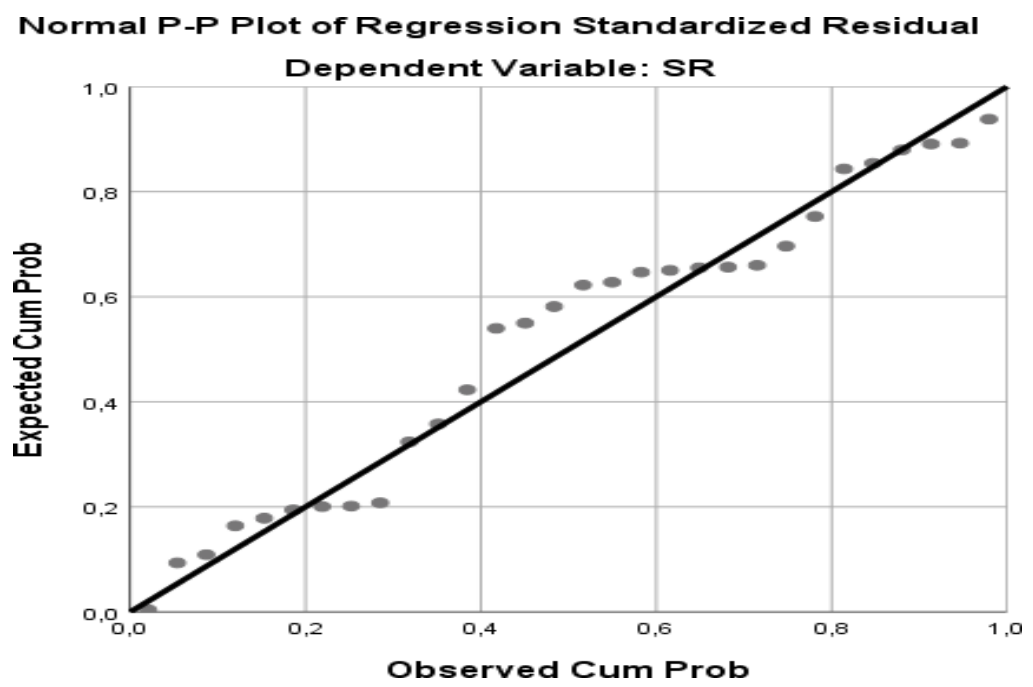

Gambar 2

Hasil Uji Normalitas menggunakan Normal P-Plot Sumber: Data yang diolah SPSS 25.0 (2019)

Berdasarkan grafik normal P-Plot diatas dapat dilihat bahwa penyebaran titik data berada disekitar garis diagonal dan mengikuti arah garis diagonal, sehingga dapat disimpulkan bahwa data dalam penelitian ini terdistribusi dengan normal.

\section{c. Uji Multikolinieritas}

Uji Multikolinieritas berguna untuk mengukur adakah korelasi antara variabel independen pada model regresi berganda. Jika nilai Variance Inflation Factor (VIF) tidak lebih dari 10 dan nilai tolerance tidak berkurang dari 0,1, maka model dapat dikatakan terbebas dari multikolinieritas (Hidayat \& Sadewa, 2020). Berikut hasilnya: 
Jurnal Akuntansi Berkelanjutan Indonesia - Vol. 3, No. 2, Mei 2020 - Nutriastuti \& Annisa

Tabel 4

Hasil Uji Multikolinieritas

Coefficients $^{\mathbf{a}}$

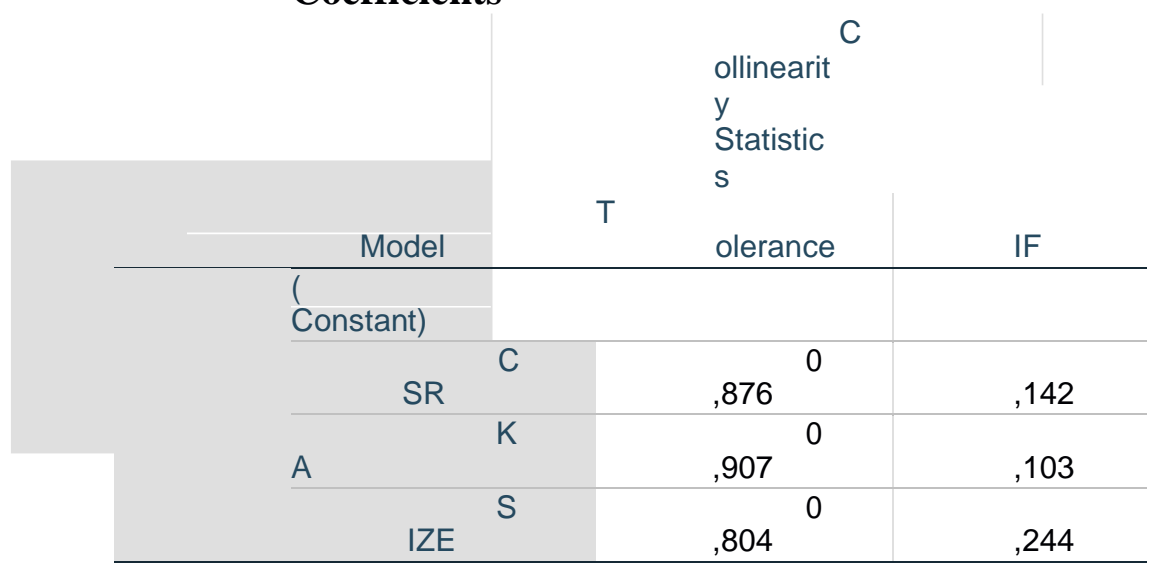

Keterangan:

Sumber: Data yang diolah SPSS 25.0 (2019)

SR = Sustainability Reporting

KA $=$ Kualitas Audit

Size = Ukuran Perusahaan

Berdasarkan tabel 4 menunjukan bahwa pada variabel Corporate Social responsibility (CSR) memiliki nilai tolerance sebesar 0,876 dan nilai VIF sebesar 1,142, pada variabel Kualitas Audit (KA) memiliki nilai tolerance sebesar 0,907 dan nilai VIF sebesar 1,103, pada variabel Ukuran Perusahaan (SIZE) memiliki nilai tolerance sebesar 0,804 dan nilai VIF sebesar 1,244. Artinya tidak terjadi multikolinearitas pada seluruh variabel independen.

\section{d. Uji Heteroskedastisitas}

Dalam uji ini digambarkan dalam kurva Scatterplot, apabila titik menyebar ke segala arah dan merata diatas dan dibawah atau sekitar angka 0, maka dapat ditarik keputusan tidak terjadi heteroskedastisitas. Berikut kurva Scatterplot: 
Jurnal Akuntansi Berkelanjutan Indonesia - Vol. 3, No. 2, Mei 2020 - Nutriastuti \& Annisa

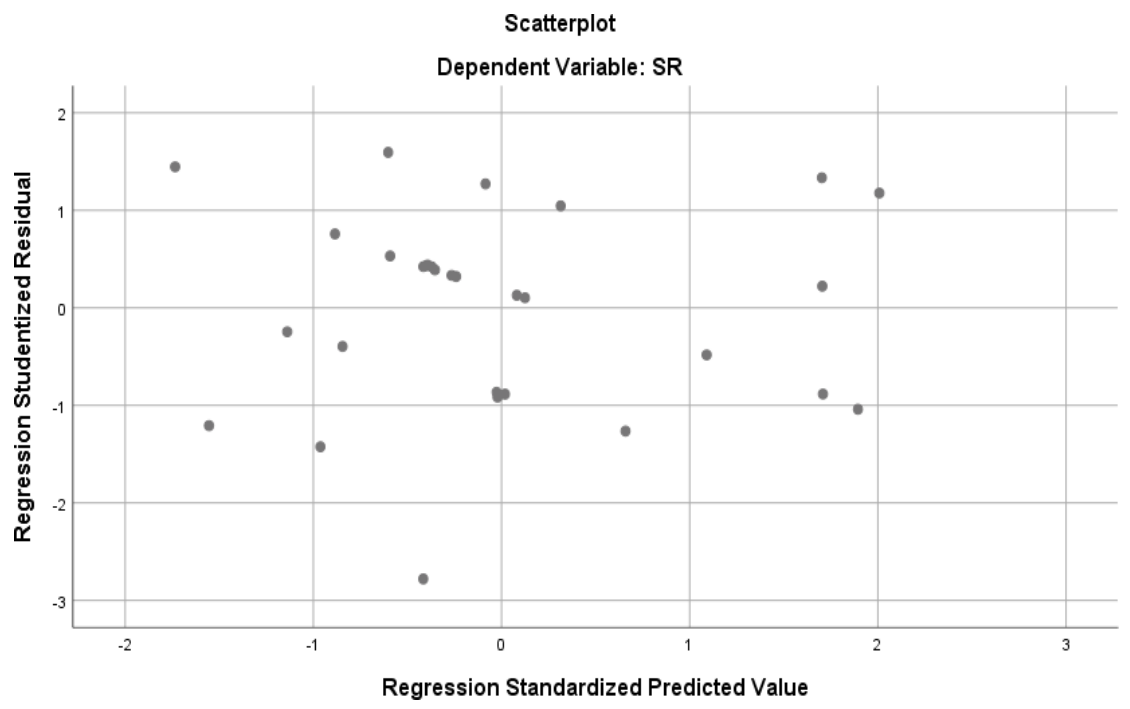

Gambar 3

Hasil Uji Heteroskedastisitas

Sumber: Data yang diolah SPSS 25.0 (2019)

Berdasarkan kurva scatterplot dapat dilihat bahwa titik-titik telah menyebar secara acak baik diatas dan dibawah angka 0 (nol) pada sumbu Y. hal ini dapat disimpulkan bahwa tidak terjadi heteroskedastisitas pada model regresi.

\section{e. Uji Autokorelasi}

\section{Tabel 5}

Hasil Uji Autokorelasi

Model Summary ${ }^{b}$

\begin{tabular}{|c|c|c|c|c|c|}
\hline \multirow[b]{2}{*}{ Model } & \multirow[b]{2}{*}{$\mathrm{R}$} & \multicolumn{3}{|c|}{ y } & \multirow[b]{2}{*}{ Durbin-Watson } \\
\hline & & R Square & $\begin{array}{ll}\text { Adjusted } & R \\
\text { Square } & \\
\end{array}$ & $\begin{array}{l}\text { Std. Error of the } \\
\text { Estimate }\end{array}$ & \\
\hline 1 & $.582^{\mathrm{a}}$ & .338 & .211 & .19277 & 1.983 \\
\hline
\end{tabular}

a. Predictors: (Constant), KA, DER, PROPER, ROA, CR

b. Dependent Variable: SRDI

Sumber: Data yang diolah SPSS 25.0 (2019)

Dilihat dari Uji Autokorelasi, syarat dikatakan lolos autokorelasi adalah nilai DU lebih kecil dari nilai DW dan nilai DW lebih kecil dari 4-DU (DU $<$ DW $<4$ DU). Pada penelitian ini dengan $\mathrm{N}$ (jumlah data) $=30$ dan $\mathrm{K}$ (variabel) $=4$ diperoleh nilai $\mathrm{DU}=1,510$. Sehingga $(1,510<1,877<(4-0,941))$.

\section{f. Uji Regresi Linear Berganda}

Penelitian ini diuji dengan menggunakan analisis regresi linear berganda dimaksudkan untuk memprediksi jika variabel independen dinaikan atau diturunkan akan mengubah 1 satuan terhadap variabel dependen. Berikut hasil 
Jurnal Akuntansi Berkelanjutan Indonesia - Vol. 3, No. 2, Mei 2020 - Nutriastuti \& Annisa

pengujian regresi linear berganda:

\section{Tabel 6}

Hasil Uji Regresi Linear Berganda

Coefficients $^{\mathrm{a}}$

\begin{tabular}{|c|c|c|c|c|c|c|c|c|}
\hline \multicolumn{9}{|c|}{ Coefficients $^{\mathrm{a}}$} \\
\hline \multirow[b]{2}{*}{ Model } & & \multicolumn{2}{|c|}{ Unstandardized Coefficients } & \multirow{2}{*}{$\begin{array}{c}\text { Standardized } \\
\text { Coefficients } \\
\text { Beta }\end{array}$} & \multirow[b]{2}{*}{$t$} & \multirow[b]{2}{*}{ Sig. } & \multicolumn{2}{|c|}{ Collinearity Statistics } \\
\hline & & $B$ & Std. Error & & & & Tolerance & VIF \\
\hline \multirow[t]{4}{*}{1} & (Constant) & .539 &, 069 & & 7,783 &, 000 & & \\
\hline & CSR &, 086 &, 032 & 479 & 2,677 &, 013 & 876 & 1,142 \\
\hline & $\mathrm{KA}$ & 016 &, 010 &, 278 & 1,581 &, 126 & 907 & 1,103 \\
\hline & SIZE & 001 &, 002 &, 118 &, 631 &, 534 & 804 & 1,244 \\
\hline
\end{tabular}

a. Dependent Variable: SR

Sumber: Data yang diolah (2019)

Berdasarkan tabel 6 dapat dilihat bahwa nilai konstanta sebesar 0,539, artinya bahwa jika variabel Corporate Social responsibility (CSR), Kualitas Audit (KA), dan Ukuran Perusahaan (SIZE) dianggap konstan atau tetap maka variabel Sustainability Reporting (SR) sebesar 0,539 dengan persamaan model regresi sebagai berikut:

$$
\mathrm{SR}=0,539+0,86 \mathrm{CSR}+0,16 \mathrm{KA}+0,001 \mathrm{SIZE}
$$

Hasil koefisien regresi menyatakan bahwa, variabel Corporate Social responsibility (CSR) ( $\beta 1$ ) memiliki nilai koefisien regresi sebesar 0,86 artinya menyatakan bahwa setiap kenaikan Corporate Social responsibility (CSR) sebesar 1 satuan akan meningkatkan Sustainability Reporting (SR) pada perusahaan yang menerbitkan Laporan Keberlanjutan di Bursa Efek Indonesia (BEI), pada variabel Kualitas Audit (KA) ( $\beta 2$ ) memiliki nilai koefisien regresi sebesar 0,16, yang artinya bahwa setiap kenaikan Kualitas Audit sebesar 1 satuan akan meningkatkan Sustainability Reporting (SR) pada perusahaan yang menerbitkan Laporan Keberlanjutan di Bursa Efek Indonesia (BEI), pada variabel Ukuran Perusahaan (SIZE) ( $\beta 3$ ) memiliki nilai koefesien regresi sebesar 0,001, yang artinya bahwa setiap kenaikan Ukuran Perusahaan sebesar 1 satuan akan meningkatkan Sustainability Reporting (SR) pada perusahaan yang menerbitkan Laporan Keberlanjutan di Bursa Efek Indonesia (BEI).

Berdasarkan hasil data maka dapat disimpulkan bahwa variabel Corporate Social responsibility (CSR), Kualitas Audit (KA), dan Ukuran Perusahaan (SIZE) berpengaruh positif terhadap Sustainibility Reporting (SR).

\section{g. Uji Koefisien Determinasi}

Koefesien Determinasi $\left(\mathrm{R}^{2}\right)$ mengukur seberapa besar kemampuan model dalam menerangkan variasi variabel dependen. Nilai $r^{2}$ yang kecil berarti kemampuan variabel-variabel independent dalam menjelaskan variasi variabel dependen amat terbatas. 
Jurnal Akuntansi Berkelanjutan Indonesia - Vol. 3, No. 2, Mei 2020 - Nutriastuti \& Annisa

\section{Tabel 7}

\section{Hasil Koefisien Determinasi}

\begin{tabular}{ll|r|r|r|r}
\multicolumn{7}{c}{ Model Summary } \\
Model & $\mathrm{R}$ & R Square & $\begin{array}{c}\text { Adjusted R } \\
\text { Square }\end{array}$ & $\begin{array}{c}\text { Std. Error of } \\
\text { the Estimate }\end{array}$ & $\begin{array}{c}\text { Durbin- } \\
\text { Watson }\end{array}$ \\
\hline 1 &, $521^{\text {a }}$ &, 271 &, 187 &, 01631 & 1,877 \\
\hline
\end{tabular}

a. Predictors: (Constant), SIZE, KA, CSR

b. Dependent Variable: SR

Sumber: Data yang diolah SPSS 25.0 (2019)

Berdasarkan tabel 7 menunjukkan bahwa nilai koefesien adjusted $R$ Square sebesar 0,187 jika dirubah kedalam persen menjadi 18,7\%, artinya variabel Corporate Social responsibility (CSR), Kualitas Audit (KA), dan Ukuran Perusahaan (SIZE) dapat menjelaskan atau menentukan variabel Sustainability Reporting (SR), sedangkan $81,3 \%$ ditentukan oleh faktor lain yang tidak diketahui dan tidak termaksud dalam analisis regresi ini.

\section{Uji Hipotesis}

a. Uji Simultan (Uji F)

Analisis uji $\mathrm{F}$ digunakan untuk mengetahui tingkat pengaruh variabel independen terhadap variabel dependen secara bersama-sama dengan membandingkan tingkat sgnifikan 0,05 . Nilai probability $\mathrm{f}$ hitung $>$ dari $\mathrm{f}$ tabel maka secara bersama-sama hipotesis diterima atau secara bersama-sama variabel independen berpengaruh terhadap variabel dependen, sebaliknya jika f hitung < dari f tabel maka secara bersama-sama hipotesis ditolak atau secara bersama-sama variabel independen tidak berpengaruh terhadap variabel dependen. Berikut hasil pengujian hipotesis secara simultan:

Tabel Uji 8

\section{Hasil Uji Simultan (Uji F)}

ANOVA $^{\mathrm{a}}$

\begin{tabular}{lll|r|r|r|r}
\multirow{2}{*}{ Model } & \multicolumn{2}{c}{$\begin{array}{c}\text { Sum of } \\
\text { Squares }\end{array}$} & df & Mean Square & F & \multicolumn{1}{c}{ Sig. } \\
\hline \multirow{2}{*}{1} & Regression &, 003 & 3 &, 001 & 3,223 &, $039^{\text {b }}$ \\
\cline { 2 - 8 } & Residual &, 007 & 26 &, 000 & & \\
\cline { 2 - 8 } & Total &, 009 & 29 & & & \\
\hline
\end{tabular}

a. Dependent Variable: SR

b. Predictors: (Constant), SIZE, KA, CSR

Sumber: Data yang diolah SPSS 25.0 (2019)

Berdasarkan tabel uji simultan ANOVA atau $\mathrm{F}$ test diatas menunjukan bahwa nilai $\mathrm{F}$ hitung sebesar 3,223 dengan taraf signifikan 0,039. Derajat pembilang (jumlah variabel -1$)=4-1=3$, dan dengan derajat penyebutan $(n-k-1)=30-4-1=25$ maka 
Jurnal Akuntansi Berkelanjutan Indonesia - Vol. 3, No. 2, Mei 2020 - Nutriastuti \& Annisa

diperoleh $\mathrm{F}$ tabel $=2,78$. Nilai $\mathrm{f}$ hitung lebih besar dari $\mathrm{f}$ tabel yaitu 3,223 $>2,78$. Dan taraf signifikan memiliki nilai 0,039 lebih kecil dari 0,05 sehingga berpengaruh signifikan terhadap Sustainability Reporting. Maka dapat disimpulkan bahwa pengujian H4 yaitu variabel Corporate Social Responsibility (CSR), Kualitas Audit dan Ukuran Perusahaan secara bersama-sama berpengaruh positif terhadap Sustainability Reporting.

\section{b. Uji Parsial (Uji t)}

Analisis Uji t merupakan uji hipotesis yang digunakan untuk menguji pengaruh masing-masing variabel independen terhadap variabel dependen, untuk menentukan nilai $\mathrm{t}$ tabel ditentukan dengan tingkat signifikan 5\% dengan derajat kebebasan $\mathrm{df}=$ (n-k-1) dimana $\mathrm{n}$ adalah jumlah data, $\mathrm{k}$ adalah jumlah variabel independent, maka df $=(30-3-1)=26$. Sehingga pada alpha sebesar 0,05 diperoleh t tabel sebesar 2,05553. adapun kriteria pengujian yang digunakan adalah:

\section{Tabel 9}

\section{Hasil Uji Parsial (Uji t)}

\begin{tabular}{|c|c|c|c|c|c|c|c|c|c|}
\hline \multirow{2}{*}{\multicolumn{2}{|c|}{ Model }} & \multicolumn{2}{|c|}{$\begin{array}{l}\text { Unstandardized } \\
\text { Coefficients }\end{array}$} & \multirow{2}{*}{$\begin{array}{c}\begin{array}{c}\text { Standardize } \\
d \\
\text { Coefficients }\end{array} \\
\text { Beta } \\
\end{array}$} & \multirow[b]{2}{*}{$\mathrm{t}$} & \multirow[b]{2}{*}{ Sig. } & \multicolumn{2}{|c|}{$\begin{array}{c}\text { Collinearity } \\
\text { Statistics }\end{array}$} & \multirow{2}{*}{$\begin{array}{c}\text { Hipotes } \\
\text { is }\end{array}$} \\
\hline & & $B$ & $\begin{array}{l}\text { Std. } \\
\text { Error }\end{array}$ & & & & $\begin{array}{c}\text { Toleranc } \\
\mathrm{e}\end{array}$ & VIF & \\
\hline \multirow[t]{4}{*}{1} & (Constant & 0,539 & 0,069 & & 7,783 & 0,000 & & & \\
\hline & CSR & 0,086 & 0,032 & 0,479 & 2,677 & 0,013 & 0,876 & 1,142 & $\begin{array}{l}\text { Gagal } \\
\text { ditolak }\end{array}$ \\
\hline & $\mathrm{KA}$ & 0,016 & 0,010 & 0,278 & 1,581 & 0,126 & 0,907 & 1,103 & Ditolak \\
\hline & SIZE & 0,001 & 0,002 & 0,118 & 0,631 & 0,534 & 0,804 & 1,244 & Ditolak \\
\hline
\end{tabular}

Sumber: Data yang diolah SPSS 25.0 (2019)

Berdasarkan tabel uji t diatas maka dapat disimpulkan bahwa:

1. Dilihat dari koefisien regresi untuk variabel Corporate Social Responsibility (CSR) mempunyai nilai positif sebesar 0,086, artinya variabel Corporate Social Responsibility (CSR) lebih kearah positif terhadap Sustainability Reporting, Dan dilihat dari $\mathrm{t}$ hitung untuk variabel Corporate Social Responsibility (CSR) diperoleh nilai 2,677 lebih besar dari t tabel 2,05553 artinya Corporate Social Responsibility (CSR) memiliki pengaruh terhadap Sustainability Reporting, dan taraf signifikan 0,013 artinya berpengarug terhadap Sustainability Reporting karna taraf signifikan lebih kecil dari 0,05 maka dapat ditarik kesimpulan bahwa pengujian Hipotesis 1 diterima yaitu Corporate Social Responsibility (CSR) berpengaruh signifikan positif terhadap Sustainability Reporting.

2 Dilihat dari koefisien regresi untuk variabel Kualitas Audit mempunyai nilai positif sebesar 0,016, artinya variabel Kualitas Audit lebih kearah positif terhadap Sustainability Reporting, Sedangkan jika dilihat dari t hitung untuk variabel Kualitas Audit diperoleh nilai sebesar 1,581 dan taraf signifikan sebesar 0,126, artinya variabel Kualitas Audit tidak berpengaruh terhadap Sustainability Reporting, ini dikarenakan pada $\mathrm{t}$ hitung lebih kecil dari 2,05553 dan taraf signifikan lebih besar dari 0,05 maka dapat di Tarik kesimpulan bahwa pengujian Hipotesis 2 ditolak yaitu Kualitas Audit tidak berpengaruh signifikan positif terhadap Sustainability Reporting. 
Jurnal Akuntansi Berkelanjutan Indonesia - Vol. 3, No. 2, Mei 2020 - Nutriastuti \& Annisa

3. Dilihat dari koefisien regresi untuk variabel Ukuran Perusahaan mempunyai nilai positif sebesar 0,001, artinya variabel Ukuran Perusahaan lebih kearah positif terhadap Sustainability Reporting, Sedangkan jika dilihat dari t hitung untuk variabel Ukuran Perusahaan diperoleh nilai sebesar 0,631 dan taraf signifikan sebesar 0,534, artinya variabel Ukuran Perusahaan tidak berpengaruh terhadap Sustainability Reporting, ini dikarenakan pada t hitung lebih kecil dari 2,05553 dan taraf signifikan lebih besar dari 0,05 maka dapat memberikan kesimpulan bahwa pengujian Hipotesis 3 ditolak yaitu Ukuran Perusahaan tidak berpengaruh signifikan positif terhadap Sustainability Reporting.

\section{KESIMPULAN DAN SARAN}

Berdasarkan hasil penelitian dan pembahasan mengenai Pengaruh Pengungkapan Corporate Social Responsibility dan Kualitas Audit terhadap Sustainability Reporting Pada Perusahaan yang Terdaftar di Bursa Efek Indonesia Tahun 2017-2018 dapat ditarik kesimpulan sebagai berikut:

1. Pengungkapan Corporate Social Responsibility memiliki pengaruh positif signifikan terhadap Sustainability Reporting.

2. Kualitas Audit tidak berpengaruh secara signifikan terhadap Sustainability Reporting, meskipun perusahaan yang menerbitkan Sustainability Reporting lebih dominan menggunakan kantor Akuntan Publik yang tergolong big four tidak mempengaruhi terhadap perusahaan yang memiliki prospek berkelanjutan yang lebih baik.

3. Ukuran Perusahaan ternyata tidak mempunyai pengaruh secara signifikan terhadap Sustainability Reporting, hal ini dikarenakan bukan hanya dilihat dari nilai Total Aset saja tetapi juga dapat dilihat dari aspek lainnya, seperti: Profitabilitas, tata Kelola Perusahaan yang baik dan lainnya.

Dalam penelitian ini masih memiliki keterbatasan, sehingga penulis ingin memberikan saran, diantaranya:

1. Dalam penelitian selanjutnya disarankan untuk spesifikasi golongan suatu perusahaan sehingga tidak ada ketimpangan dalam hasil rasio pengungkapan Corporate Social Responsibility.

2. Dalam penelitian Kualitas Audit dapat diukur tak hanya menggunakan KAP yang digunakan tetapi juga dari prosedur dari penilaian audit di perusahaan.

3. Dapat menambah variabel independen dengan menggunakan profitabilitas, Leverage dan lainnya untuk mengetahui seberapa besar dampak Sustainability Reporting terhadap perusahaan.

* Corresponding author's e-mail: : dosen00883@unpam.ac.id

http://openjournal.unpam.ac.id/index.php/JABI 
Jurnal Akuntansi Berkelanjutan Indonesia - Vol. 3, No. 2, Mei 2020 - Nutriastuti \& Annisa

\section{DAFTAR PUSTAKA}

Andriyanto, R., Effriyanti, E., \& Hidayat, A. (2018). The Effect of Spiritual Intelligence (SQ) and Personality Types on Auditor's Ability to Detect Fraud. JABI (Jurnal Akuntansi Berkelanjutan Indonesia), 1(3), 258-268.

Anis, C., \& Ghozali, I. (2001). Teori Akuntansi. In Edisi Pertama.

Arikunto. (2006). Prosedur Penelitian Suatu Pendekatan Praktik. In Ed Revisi VI. jakarta: PT Rineka Cipta.

Drs. Amin Widjaja Tunggal, A. C. (2013). POKOK-POKOK AUDITING \& JASA ASURANS. JAKARTA: HARVARINDO.

Ikatan Akuntansi Indonesia.. (2009). Standar Akuntansi Keuangan. Jakarta: Salemba Empat.

Sugiyono. (2006). Statistika untuk Penelitian. In Cetakan Ketujuh. Bandung: CV. Alfabeta.

Sugiyono. (2010). Metode Penelitian Kuantitatif Kualitatif dan R\&D . Bandung: Alfaeta.

Sugiyono.(2014). Metode Penelitian PendidikanPendekatan Kuantitatif, Kualitatif dan $R \& D$. Bandung: CV. Alfabeta.

Ahmad, F. (2014). Pengaruh karakteristik Perusahaan dan Profitabilitas terhadap Pengungkapan Sustainibility Report.

Aziz, A. (2014). Analisis Pengaruh Good Corporate Governance (GCG) terhadap

Kualitas Pengungkapan Sustainibility Report.

Fernaldy, M. F. (2016). The Impact of Profitability, Leverage and Size of Board Commissioner Toward Sustainibility Reporting Disclosure.

Hidayat, A., \& Sadewa, P. (2020). Pengaruh Penggunaan Aplikasi Eviews Terhadap Sikap Belajar dan Kemampuan Pemecahan Masalah Statistik. Edumaspul: Jurnal Pendidikan, 4(1), 321-328.

Ibrahim, M. Y. (2016). Pengaruh pengungkapan Corporate Social Responsibilty dan Kualitas Audit terhadap Sustainibility Reporting.

Maharani, S. N. (n.d.). Sustainibility Reporting sebagai Media Perusahaan dalam Menegmbangkan dan melaporkan Kebijakan Bisnis Berkelanjutan.

Mulkhan, U. d. (2011). Peran Pemerintah dalam Kebijakan Corporate Social Responsibility (CSR) dalam Upaya mendorong Pembangunan Berkelanjutan (Sustainibility Development) . Jakarta: Jurnal Ilmiah

* Corresponding author's e-mail: : dosen00883@unpam.ac.id http://openjournal.unpam.ac.id/index.php/JABI 
Jurnal Akuntansi Berkelanjutan Indonesia - Vol. 3, No. 2, Mei 2020 - Nutriastuti \& Annisa

Aministrasi Publik dan Pembangunan, Vol.2, No.1, Januari-Juni 2011.

Nugraha, B. (2015). The Influence of Good Corporate Governance (GCG) Implements Toward Quality Sustainibility Reporting (SR).

Prastiwi, H. S. (2011). Pengaruh karakteristik Perusahaan dan Corporate Governance terhadap Praktik Pengangkapan Sustainibility Report.

Putri, C. D. (2013). Pengaruh Corporate Governance dan Karakteristik Perusahaan terhadap Tanggung jawab Sosial Perusahaan didalam Sustainibility Report.

Rohmah, D. (2015). Pengaruh Mekanisme Corporate Governance, Ukuran Perusahaan dan Profitabilitas Perusahaan terhadap Pengungkapan Corporate Social Responsibilty didalam Laporan Sustainibility. Putri, 2.

Ryandi Iswandika, M. \&. (2014). Pengaruh Kinerja Keuangan, Corporate Governance, dan Kualitas Audit terhadap Pengungkapan Corporate Social Responsibility . Jakarta: JUrnal Akuntansi Fakultas Ekonomi Universitas Trisakti.

Saputro, T. S. (2016). Pengaruh Kualitas Audit dan Corporate Social Responsibilty terhadap Tax Avoidance.

The Impact of Environmental Performance, Profitability and Leverage Toward Sustainibility Reporting Disclosure. (2017).

Peraturan Pemerintah No. 47 Tahun 2012, Tentang Tanggung Jawab Sosial dan Lingkungan Perseroan Terbatas

Undang-Undang No. 40 Tahun 2007, Tentang Perseroan Terbatas UndangUndang No. 25 Tahun 2007, Tentang Penanaman Modal

Undang-Undang No. 32 Tahun 2009, Tentang Perlindungan Dan Pengelolaan Lingkungan Hidup

Widianto, H. S. (2011). Pengaruh Profitabilitas, Likuiditas, Leverage, Aktivitas, Ukuran Perusahaan dan Corporate Governance terhadap Praktik Pengungkapan Sustainibility Reporting. Semarang: Universitas Diponegoro.

William. (2012). Pengaruh Pengungkapan Corporate Social Responsibility Berdasarkan Pedoman Global Reporting Initiative Terhadap Nilai Perusahaan. Jakarta: Universitas Indonesia.

* Corresponding author's e-mail: : dosen00883@unpam.ac.id http://openjournal.unpam.ac.id/index.php/JABI 